\title{
Improved Efficacy of Newly Formulated Bacteriophages for Management of Bacterial Spot on Tomato
}

\author{
B. Balogh and J. B. Jones, Department of Plant Pathology, University of Florida, Gainesville 32611; M. T. Momol \\ and S. M. Olson, North Florida Research and Education Center, University of Florida, Quincy 32351; A. Obrado- \\ vic, Department of Plant Pathology, University of Florida, Gainesville 32611; P. King, North Florida Research and \\ Education Center, University of Florida, Quincy 32351; and L. E. Jackson, OmniLytics Inc., Salt Lake City, UT \\ 84116
}

\begin{abstract}
Balogh, B., Jones, J. B., Momol, M. T., Olson, S. M., Obradovic, A., King, P., and Jackson, L. E. 2003. Improved efficacy of newly formulated bacteriophages for management of bacterial spot on tomato. Plant Dis. 87:949-954.

Bacteriophages are currently used as an alternative method for controlling bacterial spot disease on tomato incited by Xanthomonas campestris pv. vesicatoria. However, the efficacy of phage is greatly reduced due to its short residual activity on plant foliage. Three formulations that significantly increased phage longevity on the plant surface were tested in field and greenhouse trials: (i) PCF, $0.5 \%$ pregelatinized corn flour $(\mathrm{PCF})+0.5 \%$ sucrose; (ii) Casecrete, $0.5 \%$ Casecrete $\mathrm{NH}-400+0.5 \%$ sucrose $+0.25 \%$ PCF; and (iii) skim milk, $0.75 \%$ powdered skim milk + $0.5 \%$ sucrose. In greenhouse experiments, the nonformulated, PCF-, Casecrete-, and skim milkformulated phage mixtures reduced disease severity on plants compared with the control by 1 , 30,51 , and $62 \%$, respectively. In three consecutive field trials, nonformulated phage caused 15 , 20 , and $9 \%$ reduction in disease on treated plants compared with untreated control plants, whereas plants treated with PCF- and Casecrete-formulated phage had 27, 32, and 12\% and 30, 43 , and $24 \%$ disease reduction, respectively. Plants receiving copper-mancozeb treatments were included in two field trials and had a $20 \%$ decrease in disease in the first trial and a $13 \%$ increase in the second one. Skim milk-formulated phage was tested only once and caused an $18 \%$ disease reduction. PCF-formulated phage was more effective when applied in the evening than in the morning, reducing disease on plants by 27 and 13\%, respectively. The Casecreteformulated phage populations were over 1,000-fold higher than the nonformulated phage populations $36 \mathrm{~h}$ after phage application.
\end{abstract}

Additional keywords: biological control, h-mutant

Bacterial spot of tomato (Lycopersicon esculentum Mill.) is one of the most devastating diseases in Florida and the Caribbean $(2,24)$, which can cause up to $50 \%$ losses in fruit production and makes fruit unacceptable for fresh market consumption (21). The causal agent of the disease is the gram-negative bacterium Xanthomonas campestris pv. vesicatoria, which is favored by high temperatures $\left(25\right.$ to $\left.30^{\circ} \mathrm{C}\right)$ and a wet environment (13).

Presently, two tomato races of $X$. campestris pv. vesicatoria have been found in Florida, races 1 and 3 (T1 and T3, respectively) (11). T3 strains are predominant because they have a competitive advantage over $\mathrm{T} 1$ strains in the greenhouse and field $(6,10)$. This may be due in part to the ability of $\mathrm{T} 3$ strains to produce several bacteriocin-like substances

Corresponding author: Jeffrey B. Jones

E-mail: jbjones@ufl.edu

Accepted for publication 14 March 2003.

Publication no. D-2003-0516-02R

(C) 2003 The American Phytopathological Society that specifically inhibit the growth of T1 strains (29).

Management of this disease may be achieved by integration of cultural practices, chemical control, and resistance breeding. Presently, there are no commercial tomato cultivars that are resistant to both $X$. campestris pv. vesicatoria races. Additionally, appearance of antibiotic- and copper-resistant bacterial strains in the field hindered the efficacy of chemical control $(16,27)$. If weather conditions are favorable for disease development, there are no adequate control measures to manage the disease (13).

Several alternative control methods have been investigated in recent years. Systemic acquired resistance (SAR) inducers, such as acibenzolar- $S$-methyl and harpin, have been shown to be active against bacterial diseases of tomato $(15,22)$, and their use in control of bacterial spot is the subject of ongoing research (20). Biological control of the disease has been attempted by using a nonpathogenic T3 strain to antagonize the T1s (14) and with other antagonistic bacteria such as Pseudomonas putida B56 and Pseudomonas syringae Cit7 (30). Plant growth promoting rhizobacteria (PGPR) that induce SAR have been successfully used for controlling bacterial speck of tomato (9).

Another approach for biological control is the use of bacterial viruses or bacteriophages (phages) to control bacterial diseases. Phages have long been proposed as plant disease control agents (19) and have been used in several plant-bacterium pathosystems $(3,8,12,23,26,28,31)$. In field trials in 1997 and 1998, twice-weekly early-morning spray applications of a mixture of four phages specific to $X$. campestris pv. vesicatoria $\mathrm{T} 1$ and $\mathrm{T} 3$ bacteria reduced disease severity of bacterial spot on plants by an average of $17 \%$, whereas a copper-mancozeb application, the standard chemical treatment, caused only $11 \%$ reduction on treated plants (4). Additionally, phage-treated plants were found to be significantly more vigorous than coppertreated and nontreated ones, and they yielded significantly more extra large fruits, as well.

However, J. B. Jones (unpublished data) noted that the late morning applications of phage were ineffective for controlling bacterial spot, and speculated that phage endurance was significantly reduced. Viruses are very fragile and cannot reside long on plant foliage because they are quickly eliminated by harmful environmental factors such as rain and sunlight-UV $(18,31)$. Therefore, the need arose to develop formulations and/or change the application strategy, such as time of application, in order to protect phage particles from harmful environmental factors. The accordingly enhanced residual activity of the phages could lead to increased efficacy of phage treatments and to a more convenient application schedule. Previously, we developed three formulations that significantly increased phage longevity on tomato foliage (1). The objective of this project was to investigate in greenhouse and field experiments whether the use of selected formulations enhanced the efficacy of bacteriophage treatment for controlling bacterial spot of tomato. We also examined whether the timing of phage application influenced the efficacy of disease control.

\section{MATERIALS AND METHODS}

Bacterial strains. $X$. campestris pv. vesicatoria strains $\mathrm{BD} 2$ and 91-118 (to- 
mato race $\mathrm{T} 3$ ) and $\mathrm{CS} 1 \mathrm{~L}$ (tomato race 1) were isolated from symptomatic tomatoes collected in Florida. The bacteria were grown at $28^{\circ} \mathrm{C}$ on nutrient agar (NA) medium $(0.8 \%$ nutrient broth [BBL, Becton Dickinson and Co., Cockeysville, MD] and 1.5\% Bacto Agar [Difco, Becton Dickinson and Co., Sparks, MD]).

Bacteriophages. Clear-plaque producing, lytic phages specific for each of the hosts (BD2, 91-118 [race 3], and CS1L [race 1]) were isolated originally from either tomato/pepper plant parts, i.e., leaves, stems, etc., or soil, field runoff, river and stream waters. One h-mutant phage each for BD2 and CS1L was also isolated. Six phages for each host were produced by inoculating log phase cultures (approximately $1 \times 10^{8} \mathrm{CFU} / \mathrm{ml}$ ) in nutrient broth $/ 0.2 \%$ yeast $/ 0.25 \%$ glucose with a multiplicity of infection varying between 0.01 and 1.0. Vigorous shaking of viralhost mixtures continued for a minimum of $9 \mathrm{~h}$ to overnight at $28^{\circ} \mathrm{C}$. Bacterial debris and survivors were removed by centrifugation at $10,000 \times g$ for $10 \mathrm{~min}$. Each suspension was titered to make certain there were at least $10^{9}$ plaque forming units (PFU)/ml. Appropriate mixtures for each host were prepared and sterilized through a $0.2-\mu \mathrm{m}$ microbiological filter. The finalized phage mixtures (Agriphage, OmniLytics Inc., Salt Lake City, UT) that consisted of six to eight different phages and had an approximate final titer of $1 \times 10^{10} \mathrm{PFU} / \mathrm{ml}$ were stored at $4^{\circ} \mathrm{C}$ until use.

Bacterial inoculation. Bacteria were removed from NA plates after $24 \mathrm{~h}$, suspended in sterile tap water, and adjusted to $A_{600}=0.3$, which is approximately $10^{8}$
$\mathrm{CFU} / \mathrm{ml}$. The bacterial suspensions were misted on tomato plants using a hand-held plastic sprayer. In greenhouse experiments all plants were sprayed, while in field experiments only the middle plant of each plot was inoculated following addition of 0.025\% Silwet L-77 (Loveland Industries Inc., Greeley, $\mathrm{CO}$ ) to the bacterial inoculum.

Greenhouse experiments. 'Bonny Best' seedlings were grown in $10-\mathrm{cm}$ pots in Terra-Lite agricultural mix (The Scotts Co., Marysville, OH). Plants were grown in the greenhouse at 23 to $28^{\circ} \mathrm{C}$, fertilized and watered as needed. The treatments were applied when the tomato plants reached the four- to five-leaf stage, on 5 November and 3 December 2001, in experiments 1 and 2 , respectively. The treatments and their constitution are shown in Table 1.

Two hours after the application of treatments, the plants were inoculated with strain BD2. Following inoculation, each plant was sealed within a plastic bag in order to maintain high relative humidity. The plants were placed in a growth chamber at $28^{\circ} \mathrm{C}$ and $12-\mathrm{h}$ photoperiod for $48 \mathrm{~h}$. The plastic bags were removed and the plants were transferred to the greenhouse where they were arranged in a completely randomized block design.

Plants were assessed for disease severity 14 days after inoculation. On each plant, the number of lesions was determined on five leaflets of each of three different leaves. For statistical analysis, the data for each leaflet were transformed using $\log$ transformation $\left[y=\log _{10}(x+1)\right]$, and then the $\log$ values were averaged for each plant. The data were then subjected to an analysis of variance (ANOVA) followed by determining differences between treatment means by Duncan's multiple range test using SAS System for Windows program release 8.02 (SAS Institute, Cary, NC).

Field experiments. Three field experiments were conducted. Experiment 1 was conducted at the Horticultural Research Unit of the University of Florida in Gainesville, in the 2001 spring growing season, while experiments 2 and 3 were conducted at the IFAS North Florida Research and Education Center in Quincy, in the 2001 spring and fall growing seasons, respectively. Treatments used in the field experiments are shown in Table 1. Five replications were implemented for each treatment, and the plots were arranged in a randomized complete block design. Each plot consisted of 11 plants. There were 6.1 $\mathrm{m}$ between rows and between plots within the same row. Plants were spaced $51 \mathrm{~cm}$ apart within each plot. The plants were cultured according to standard horticultural methods with drip irrigation and plastic mulch (17). In experiments 1, 2, and 3, 'Mountain Fresh', 'BHN 444', and 'BHN555 ' tomato varieties were used, respectively. Seedlings were initially grown in the greenhouse and then transplanted to the field. Pathogen inoculation was done about 2 weeks after transplanting. Treatment applications were begun before inoculation and were continued until 2 weeks before harvest. All phage treatments were applied twice weekly in the evenings, except the PCFmorning treatment, which was applied twice weekly in the morning. Copper-mancozeb treatment was applied once a week.

Table 1. Ingredients used to prepare treatments applied in greenhouse and field experiments, with amounts based on 1-liter spray mix

\begin{tabular}{|c|c|c|c|c|c|c|c|c|c|}
\hline Experiment & Formulation & $\begin{array}{c}\text { Casecrete }^{\mathrm{u}} \\
\text { (g) }\end{array}$ & $\begin{array}{c}\mathbf{P C F}^{\mathrm{v}} \\
(\mathrm{g})\end{array}$ & $\begin{array}{l}\text { Dry skim } \\
\text { milkw }(g)^{\mathrm{w}}(\mathrm{s})\end{array}$ & $\begin{array}{l}\text { Sucrose } \\
\text { (g) }\end{array}$ & $\begin{array}{c}\text { Penncozeb }^{x} \\
\text { (g) }\end{array}$ & $\begin{array}{l}\text { Kocide }^{y} \\
\text { (g) }\end{array}$ & $\begin{array}{c}\text { Agriphage }^{\mathrm{z}} \\
\text { anti-T3 (ml) }\end{array}$ & $\begin{array}{c}\text { Agriphage } \\
\text { anti-T1 (ml) }\end{array}$ \\
\hline \multirow[t]{6}{*}{ Greenhouse } & Skim milk & & & 7.5 & 5 & & & 5 & \\
\hline & Casecrete & 5 & 2.5 & & 5 & & & 5 & \\
\hline & PCF & & 5 & & 5 & & & 5 & \\
\hline & Nonformulated & & & & & & & 5 & \\
\hline & Skim milk, no phage & & & 7.5 & 5 & & & & \\
\hline & Casecrete, no phage & 5 & 2.5 & & 5 & & & & \\
\hline \multirow[t]{4}{*}{ Field 1} & PCF, evening & & 5 & & 5 & & & 10 & 10 \\
\hline & PCF, morning & & 5 & & 5 & & & 10 & 10 \\
\hline & Casecrete & 5 & 2.5 & & 5 & & & 10 & 10 \\
\hline & Nonformulated & & & & & & & 10 & 10 \\
\hline \multirow[t]{4}{*}{ Field 2} & Copper-mancozeb & & & & & 2.4 & 3.6 & & \\
\hline & Casecrete & 5 & 2.5 & & 5 & & & 5 & 5 \\
\hline & PCF & & 5 & & 5 & & & 5 & 5 \\
\hline & Nonformulated & & & & & & & 5 & 5 \\
\hline \multirow[t]{5}{*}{ Field 3} & Copper-mancozeb & & & & & 2.4 & 3.6 & & \\
\hline & Casecrete & 5 & 2.5 & & 5 & & & 5 & 5 \\
\hline & PCF & & 5 & & 5 & & & 5 & 5 \\
\hline & Skim milk & & & 7.5 & 5 & & & 5 & 5 \\
\hline & Nonformulated & & & & & & & 5 & 5 \\
\hline
\end{tabular}

u Casecrete NH-400 (American Casein Company, Burlington, NJ).

${ }^{\mathrm{v}}$ Pregelatinized corn flour (PCPF 400, Lauhoff Grain Co., Danville, IL).

w Dehydrated Skim Milk (Difco Laboratories, Detroit, MI) in greenhouse experiments and Instant Nonfat Dry Milk, fortified with vitamins A\&D (Astor

Products, Inc., Jacksonville, FL) in the third field experiment.

x Penncozeb 75DF (Griffin Corporation, Valdosta, GA).

${ }^{y}$ Kocide 2000 (Griffin Corporation).

${ }^{z}$ Agriphage (OmniLytics, Salt Lake City, UT): mixture of six to eight lytic bacteriophages active against the indicated race of Xanthomonas campestris pv. vesicatoria. Approximate titer of phage mixtures was $1 \times 10^{10}$ plaque forming units $(\mathrm{PFU}) / \mathrm{ml}$. 
Collection, processing, and analysis of field data. Disease ratings were carried out three to four times during the growing season. Two types of disease ratings were performed: (i) assessment of disease severity using the Horsfall-Barratt (HB) scale (7) and then calculating the area under the disease progress curve (AUDPC) (25), and (ii) assessment of lesion numbers on terminal leaflets (from 8 to 10 leaflets per plot). For statistical analysis, the lesion numbers from leaflets from each plot were averaged following log transformation $\left[y=\log _{10}(x+1)\right]$. The data were subjected to an analysis of variance (ANOVA) followed by determining differences between treatment means by the Duncan's multiple range test (DMRT). For yield data analysis, harvested fruits were classified into medium, large, and extra-large groups according to current Florida standards (5), and the number and weight for each class and cull weight were recorded for each plot. The raw data were subjected to ANOVA analysis and DMRT.

Phage population analysis. The changes in $\mathrm{T} 1$ phage populations were assessed twice during the 2001 spring field experiment in Quincy. Following the 1 and 22 May evening phage applications, leaf samples were collected from all plots three times: in the morning and afternoon the day following the evening application, and then in the morning the following day. Each sample consisted of 10 terminal leaflets that were located on exposed positions of the plants. The leaflets were placed into zipper-seal plastic freezer bags. The bags were sealed, placed into a portable ice cooler, and transferred to the laboratory. In the laboratory, each bag was weighed, and then $100 \mathrm{ml}$ of deionized water was poured into each bag. The bags were shaken on a Wrist Action shaker (Burrel Co., Oakland, $\mathrm{CA}$ ) for $15 \mathrm{~min}$, and then $1 \mathrm{ml}$ of the rinsate was transferred to $1.5-\mathrm{ml}$ microcentrifuge tubes. Then $100 \mu \mathrm{l}$ of chloroform was added to each microcentrifuge tube, and the tubes were incubated on a rotary shaker for $30 \mathrm{~min}$. Following incubation, the chloroform was pelleted by a pulse-spin in a microcentrifuge and $700 \mu \mathrm{l}$ of the supernatant was transferred into a sterile microcentrifuge tube. The tube was centrifuged for $15 \mathrm{~min}$ at $14,000 \mathrm{rpm}$ in order to remove cellular debris. The supernatant was used for enumeration of the phage titer following preparation of a dilution series.

For enumeration, bacterial cells from a 24-h-old bacterial culture were removed from the agar plates and suspended in sterile tap water. A $100-\mu l$ aliquot of the phage suspension was placed in a sterile $90-\mathrm{mm}$ diameter petri dish (Fisher Scientific Co., Fair Lawn, NJ) followed by the addition of $100 \mu \mathrm{l}$ of the suspension of the host bacterium (strain CS1L). Finally, $16 \mathrm{ml}$ of NYA medium $(0.8 \%$ [wt/vol] nutrient broth; $0.6 \%$ [wt/vol] Bacto Agar, and 0.2\% [wt/vol] yeast extract [Difco, Becton Dick- inson and Co., Sparks, MD]), heated to 48 to $50^{\circ} \mathrm{C}$, was added. The medium was swirled in the petri dish to facilitate thorough mixing of bacterial cells and the phage virions. The plate was incubated at $28^{\circ} \mathrm{C}$ for 2 to 3 days until the bacterial lawn appeared and the plaques became visible.

The plaques were counted at the suitable dilutions, and the phage titer was expressed as number of plaque forming units (PFU) per gram of leaf tissue by the following equation: $y=$ plaque number $\times 1,000$ (since $100 \mu \mathrm{l}$ of the original $100-\mathrm{ml}$ volume was plated)/dilution ratio/[sample bag weight empty bag weight (g)]. For statistical analysis, the data acquired from each sample were transformed using log transformation $\left[z=\log _{10}(y+1)\right]$ and then subjected to
ANOVA analysis and Duncan's multiple range test.

\section{RESULTS}

Effect of bacteriophage formulations on bacterial spot disease development in the greenhouse. Application of phage mixture in water did not reduce the lesion number on plants compared with the untreated control (Table 2). However, the phage mixture in all three protective formulations significantly reduced the lesion numbers in at least one of the two experiments. The skim milk formulation achieved the greatest reduction in disease, $79 \%$ in the first experiment and $45 \%$ in the second one. Skim milk, PCF, and Casecrete formulations, applied without phage, did not reduce the lesion numbers.

Table 2. Effect of phage formulations on bacterial spot disease development on tomato in the greenhouse

\begin{tabular}{lccc}
\hline & \multicolumn{3}{c}{ Average lesion number $^{\mathbf{y}}$} \\
\cline { 2 - 4 } Treatment $^{\mathbf{z}}$ & Experiment 1 & Experiment 2 & Experiment 3 $^{-}$ \\
\hline Skim milk & $10.1 \mathrm{~b}$ & $0.6 \mathrm{~d}$ & $4.6 \mathrm{~d}$ \\
Casecrete & $13.7 \mathrm{~b}$ & $1.2 \mathrm{~d}$ & $5.6 \mathrm{~cd}$ \\
PCF & $10.8 \mathrm{a}$ & $1.0 \mathrm{~d}$ & $16.5 \mathrm{ab}$ \\
Non-formulated & $20.4 \mathrm{a}$ & $0.9 \mathrm{~d}$ & $6.2 \mathrm{bcd}$ \\
Skim milk - no phage & $20.7 \mathrm{a}$ & $7.7 \mathrm{ab}$ & $13.8 \mathrm{abc}$ \\
Casecrete - no phage & $20.4 \mathrm{a}$ & $6.3 \mathrm{~b}$ & $11.6 \mathrm{a}-\mathrm{d}$ \\
PCF - no phage & $\mathrm{NT}$ & $11.8 \mathrm{a}$ & $21.1 \mathrm{a}$ \\
Untreated control & $18.5 \mathrm{a}$ & $3.7 \mathrm{c}$ & $12.2 \mathrm{a}-\mathrm{d}$ \\
\hline
\end{tabular}

y Average lesion number per leaflet 14 days after inoculation. Means followed by different letters within a column are significantly different according to Duncan's multiple range test, $P=0.05$ level.

${ }^{\mathrm{z}}$ The constitution of treatments is shown in Table 1.

Table 3. Effect of phage formulations on bacterial spot disease development on tomato in the field in spring 2001 in Gainesville, FL

\begin{tabular}{lccl}
\hline & \multicolumn{2}{c}{ Average lesion number per leaflet $^{\mathbf{x}}$} & \\
\cline { 2 - 3 } Treatment $^{\mathbf{y}}$ & May 21 & June 4 & AUDPC $^{\mathbf{z}}$ \\
\hline PCF-evening & $1.3 \mathrm{c}$ & $6.4 \mathrm{bc}$ & $46.7 \mathrm{~cd}$ \\
PCF-morning & $3.8 \mathrm{~b}$ & $10.0 \mathrm{~b}$ & $55.5 \mathrm{~b}$ \\
Casecrete & $1.0 \mathrm{c}$ & $3.9 \mathrm{c}$ & $44.6 \mathrm{~d}$ \\
Nonformulated & $2.6 \mathrm{bc}$ & $8.5 \mathrm{~b}$ & $54.1 \mathrm{bc}$ \\
Untreated control & $11.0 \mathrm{a}$ & $26.3 \mathrm{a}$ & $63.9 \mathrm{a}$ \\
\hline
\end{tabular}

${ }^{x}$ Means followed by different letters within a column are significantly different according to Duncan's multiple range test, $P=0.05$ level.

${ }^{\mathrm{y}}$ All treatments were applied twice weekly in the evenings, with the exception of PCF-morning treatment that was applied in the mornings. The constitution of the treatments is shown in Table 1.

${ }^{\mathrm{z}}$ Area under the disease progress curve.

Table 4. Effect of phage formulations on bacterial spot disease development on tomato in the field in spring 2001 in Quincy, FL

\begin{tabular}{lccccc}
\hline & \multicolumn{4}{c}{ Average lesion number per leaflet $^{\mathbf{x}}$} & \\
\cline { 2 - 5 } Treatment $^{\mathbf{y}}$ & May 2 & May 24 & June 7 & June 21 & AUDPC $^{\mathbf{z}}$ \\
\hline Copper-mancozeb & $5.5 \mathrm{~b}$ & $6.3 \mathrm{ab}$ & $2.8 \mathrm{~b}$ & $9.8 \mathrm{~b}$ & $48.2 \mathrm{~b}$ \\
PCF & $3.4 \mathrm{~b}$ & $6.0 \mathrm{~b}$ & $2.4 \mathrm{~b}$ & $4.1 \mathrm{bc}$ & $40.9 \mathrm{c}$ \\
Casecrete & $3.8 \mathrm{~b}$ & $1.6 \mathrm{c}$ & $1.9 \mathrm{~b}$ & $1.8 \mathrm{~cd}$ & $34.4 \mathrm{~d}$ \\
Nonformulated & $7.2 \mathrm{~b}$ & $7.2 \mathrm{ab}$ & $3.2 \mathrm{~b}$ & $6.0 \mathrm{~b}$ & $48.4 \mathrm{~b}$ \\
Untreated control & $9.8 \mathrm{a}$ & $12.8 \mathrm{a}$ & $7.3 \mathrm{a}$ & $25.7 \mathrm{a}$ & $60.3 \mathrm{a}$ \\
\hline
\end{tabular}

${ }^{x}$ Means followed by different letters within a column are significantly different according to Duncan's multiple range test, $P=0.05$ level.

${ }^{y}$ All treatments were applied twice weekly in the evenings. The constitution of the treatments is shown in Table 1.

${ }^{\mathrm{z}}$ Area under the disease progress curve. 
Effect of phage formulations on bacterial spot disease development in the field. In the 2001 spring growing season in Gainesville, all phage treatments caused significant reduction in both lesion numbers and disease severity compared with

Table 5. Effect of phage formulations on bacterial spot disease development on tomato on the field in fall 2001 in Quincy, FL

\begin{tabular}{lccccc}
\hline & \multicolumn{5}{c}{ Average lesion number per leaflet } \\
\cline { 2 - 6 } Treatment $^{\mathbf{y}}$ & Aug 30 & Sept 13 & Sept 27 & Oct 8 & AUDPC $^{\mathbf{z}}$ \\
\hline Copper-mancozeb & $16.1 \mathrm{a}$ & 18.5 & 1.4 & 9.4 & $158.7 \mathrm{a}$ \\
PCF & $4.5 \mathrm{bc}$ & 14.8 & 1.3 & 7.8 & $123.3 \mathrm{c}$ \\
Casecrete & $1.9 \mathrm{c}$ & 11.7 & 2.1 & 9.1 & $106.8 \mathrm{~d}$ \\
Skim milk & $1.5 \mathrm{c}$ & 11.4 & 1.5 & 7.1 & $115.1 \mathrm{~cd}$ \\
Nonformulated & $4.4 \mathrm{bc}$ & 25.6 & 2.2 & 9.3 & $127.9 \mathrm{bc}$ \\
Untreated control & $8.8 \mathrm{ab}$ & 21.6 & 2.1 & 11.0 & $140.4 \mathrm{~b}$ \\
\hline
\end{tabular}

${ }^{x}$ Means followed by different letters within a column are significantly different according to Duncan's multiple range test, $P=0.05$ level.

${ }^{y}$ All treatments were applied twice weekly in the evenings. The constitution of the treatments is shown in Table 1.

${ }^{\mathrm{z}}$ Area under the disease progress curve. the untreated control (Table 3). According to the AUDPC data, the Casecreteformulated phage treatment was the most effective in disease control, being significantly more efficient than the nonformulated phage treatment. The PCF-formulated phage treatment was significantly more effective if applied in the evening instead of morning. Fruit yield was not assessed in this experiment.

In spring 2001 in Quincy, all treatments reduced the number of lesions on the plants; however, only in the case of the PCF- and Casecrete-formulated phage treatments was this reduction significant in all four rating times (Table 4). According to the AUDPC results, the nonformulated phage treatment significantly reduced disease severity compared with the control and achieved a level of control similar to copper-mancozeb treatment, whereas both PCF and Casecrete formulations significantly further increased the efficacy of phage treatment. The Casecrete formulation was significantly more effective than PCF. Despite differences in disease progress, there were no significant differences in yield among the different treatments (data not shown).
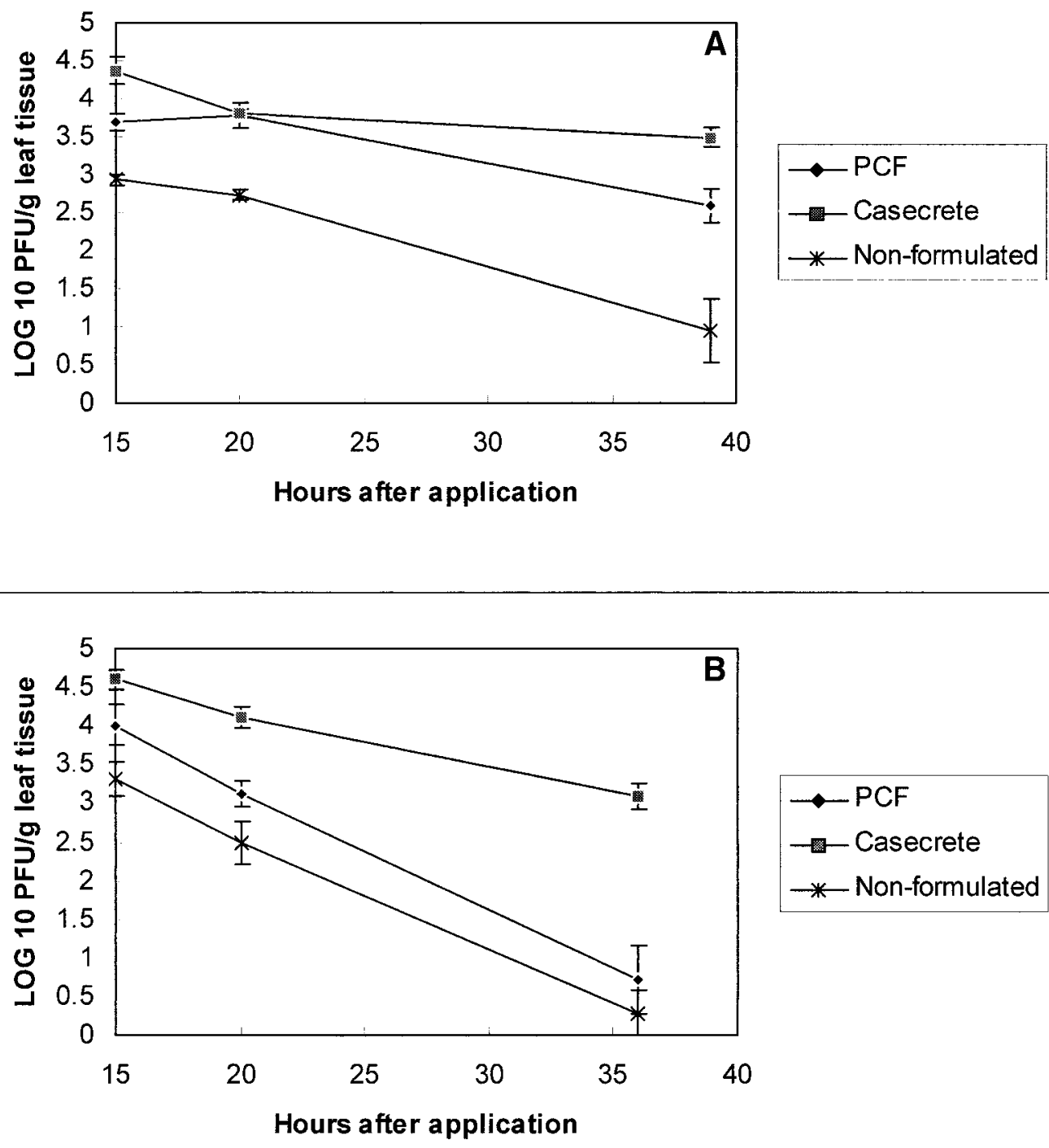

Fig. 1. Recovery of bacteriophages from tomato leaf surface. Formulations were applied on tomato plants on A, 1 May $2001,7: 30$ P.M., and B, 22 May 2001, 7 P.M. Error bars indicate standard error. 
In the fall 2001 growing season in Quincy, the skim milk formulation was also included. The disease was more severe than in the previous two experiments; thus the lesion count data did not show significant differences among treatments as the season progressed (Table 5). According to the AUDPC values, the nonformulated phage treatment did not cause a significant reduction in disease severity compared with the control, but the reduction was significant for all three formulations used. Interestingly, disease development was significantly higher on copper-mancozeb treated plots than on the control. No significant differences were found in yield among the treatments (data not shown).

Effect of protective formulations on phage longevity in the field. Changes in anti-T1 phage populations were assessed on two occasions during the second field experiment. Since $X$. campestris pv. vesicatoria race $\mathrm{T} 1$ bacteria, the host of anti$\mathrm{T} 1$ phages, was not present in the field due to the antagonistic effect of $X$. campestris pv. vesicatoria $\mathrm{T} 3$, the changes in anti-T1 phage reflected changes of phage populations applied in a host-free environment. Nonformulated phage populations were quickly reduced and practically eliminated by $36 \mathrm{~h}$ after application (Fig. 1). PCF formulation significantly decreased the rate of reduction during the first assessment, but not during the second one. Casecrete formulation, on the other hand, performed uniformly in both assessments, slowing the reduction rate significantly and contributing to approximately 1,000-fold higher phage populations $36 \mathrm{~h}$ after application compared with phages applied without protective formulation.

\section{DISCUSSION}

Bacteriophages were introduced for control of bacterial spot of tomato in the 1990s (4). Twice weekly applications of a mixture of four host range mutant phages that were active against the causal agent of the disease resulted in significantly better disease control than the standard coppermancozeb treatment. Additionally, the yield of extra-large fruits was significantly higher on bacteriophage-treated plants than on copper-mancozeb treated ones. However, phage treatment was effective only when applied early in the morning, before dawn. The short residual activity of the control agents hindered the efficacy of phage treatment when applied during daytime. Bacteriophages are rapidly degraded in the field and practically disappear from tomato foliage 2 days after application (Fig. 1).

The use of formulations that increase bacteriophage longevity could improve the efficacy of phage treatment and allow more convenient application time. Several such protective formulations were identified in earlier studies (1), and three of them were selected for disease control trials: (i) PCF
+ sucrose; (ii) Casecrete + sucrose + PCF; and (iii) skim milk + sucrose. These formulations increased the concentration of phage populations 2 days after the application 4,700-, 38,500-, and 100,000-fold, respectively (1).

In this study, use of protective formulations significantly increased the efficacy of bacteriophage treatments for disease control both in the greenhouse and in the field. Skim milk gave the best results in greenhouse trials, while Casecrete performed best in the field. Of the three formulations tested, skim milk was easiest to prepare and apply. Our results also indicated that evening applications resulted in better control than morning applications.

Despite the improved efficacy in disease control, none of the treatments achieved a significant increase in yield. This could have been the result of the highly contagious nature of phage infection: phages were detected in many nontreated plots in the middle of the season in the spring field experiment in Quincy, and in all plots by the end of the growing season in the fall field experiment.

In summary, our results indicated that the efficacy of phage treatment could be increased by use of protective formulations and by proper timing of applications. Nevertheless, further research is needed to optimize formulations, application frequency, phage dose, and the constitution of phage mixtures so that phage treatment could stand as a valid alternative to chemical bactericides for treatment of bacterial plant diseases in the future.

\section{ACKNOWLEDGMENTS}

This research was supported by the Florida Agricultural Experiment Station and approved for publication as Journal Series No. R-09297 by the USDA Southern Region IPM (J. B. Jones, M. T. Momol, and S. M. Olson, USDA 00-34103-9094) and USDA T-STAR (J. B. Jones, M. T. Momol, and S. M. Olson, USDA 2002-34135-12348).

\section{LITERATURE CITED}

1. Balogh, B. 2002. Strategies for improving the efficacy of bacteriophages for controlling bacterial spot of tomato. M.S. thesis. University of Florida, Gainesville.

2. Bouzar, H., Jones, J. B., Stall, R. E., Louws, F. J., Schneider, M., Rademaker, J. L. W., de Bruijn, F. J., and Jackson, L. E. 1999. Multiphasic analysis of xanthomonads causing bacterial spot disease on tomato and pepper in the Caribbean and Central America: Evidence for common lineages within and between countries. Phytopathology 89:328-335.

3. Coons, G. H., and Kotila, J. E. 1925. The transmissible lytic principle (bacteriophage) in relation to plant pathogens. Phytopathology 15:357-370,

4. Flaherty, J. E., Jones, J. B., Harbaugh, B. K., Somodi, G. C., and Jackson, L. E. 2000. Control of bacterial spot on tomato in the greenhouse and field with h-mutant bacteriophages. HortScience 35:882-884.

5. Florida Tomato Committee. 2002. Florida Tomato Facts and Sizing. Fla. Tomato Comm. Online, publication fact_size.

6. Hert, A. P. 2001. Relative importance of bacteriocin-like genes in antagonism of $\mathrm{T} 3$ to $\mathrm{T} 1$ strains of Xanthomonas campestris pv. vesicatoria. M.S. thesis. University of Florida, Gainesville.

7. Horsfall, J. G., and Barratt, R. W. 1945. An improved system for measuring plant disease. Phytopathology 35:655.

8. Jackson, L. E. 1989. Bacteriophage prevention and control of harmful plant bacteria. U.S. Patent No. 4,828,999.

9. Ji, P., Kloeppe, J. W., Wilson, M., and Campbell, H. L. 1996. Rhizobacterial-induced systemic resistance in tomato against bacterial speck. (Abstr.) Phytopathology 86:S50.

10. Jones, J. B., Bouzar, H., Somodi, G. C., Stall, R. E., Pernezny, K., El-Morsy, G., and Scott, J. W. 1998. Evidence for the preemptive nature of tomato race 3 of Xanthomonas campestris pv. vesicatoria in Florida. Phytopathology 88:33-38.

11. Jones, J. B., Stall, R. E., Scott, J. W., Somodi, G. C., Bouzar, H., and Hodge, N. C. 1995. A third tomato race of Xanthomonas campestris pv. vesicatoria. Plant Dis. 79:395-398.

12. Kotila, J. E., and Coons, G. H. 1925. Investigations on the blackleg disease of potato Mich. Agric. Exp. Stn. Tech. Bull. 67:3-29.

13. Kucharek, T. 1994. Plant pathology fact sheet: Bacterial spot of tomato and pepper. University of Florida, Institute of Food and Agricultural Sciences, Plant Pathology Department, Cooperative Extension Service. Online, publication BODY_VH007.

14. Liu, T. 1998. Biological control of tomato bacterial spot with a hrp-mutant of Xanthomonas campestris pv. vesicatoria. M.S. thesis. University of Florida, Gainesville.

15. Louws, F. J., Wilson, M., Campbell, H. L., Cuppels, D. A., Jones, J. B., Shoemaker, P. B. Sahin, F., and Miller, S. A. 2001. Field control of bacterial spot and bacterial speck of tomato using a plant activator. Plant Dis. 85:481-488.

16. Marco, G. M., and Stall, R. E. 1983. Control of bacterial spot of pepper initiated by strains of Xanthomonas campestris pv. vesicatoria that differ in sensitivity to copper. Plant Dis. 67:779-781.

17. Maynard, D. N., Hochmuth, G. J., Olson, S. M., Vavrina, C. S., Stall, W. M., Kucharek, T. A., Webb, S. E., Taylor, T. G., and Smith, S. A. 2001. Tomato production in Florida. Pages 257-267 in: Vegetable production guide for Florida, 2001-2002. D. N. Maynard and S. M. Olson, eds. University of Florida, Institute of Food and Agricultural Sciences Extension Service, Gainesville.

18. McGuire, M. R., Tamez-Guerra, P., Behle, R. W., and Streett, D. A. 2001. Comparative Field Stability of Selected Entomopathogenic Virus Formulations. J. Econ. Entomol. 94:1037-1044.

19. Moore, E. S. 1926. D'Herelle's bacteriophage in relation to plant parasites. S. Afr. J. Sci. 23:306.

20. Obradovic, A., Jones, J. B., Momol, M. T. Olson, S. M., King, P. C., and Balogh, B. 2002. Management of tomato bacterial spot in the field by foliar applications of bacteriophages and SAR inducers. (Abstr.) Phytopathology 92:S60.

21. Pohronezny, K., and Volin, R. B. 1983. The effect of bacterial spot on yield and quality of fresh market tomatoes. HortScience 18:69-70.

22. Qui, D., Wei, Z. M., Bauer, D. W., and Beer, S. V. 1997. Treatment of tomato seed with harpin enhances germination and growth and induces resistance to Ralstonia solanacearum. (Abstr.) Phytopathology 87:S80.

23. Saccardi, A., Gambin, E., Zaccardelli, M., Barone, G., and Mazzucchi, U. 1993. Xanthomonas campestris pv. pruni control trials with phage treatments on peaches in the orchard. Phytopathol. Mediterr. 32:206-210

24. Scott, J. W., and Jones, J. B. 1984. A source of 
resistance to bacterial spot (Xanthomonas campestris pv. vesicatoria). Tomato Genet. Coop. Newsl. 34:16.

25. Shaner, G., and Finney, R. E. 1977. The effect of nitrogen fertilization on the expression of slow-mildewing resistance in Knox wheat. Phytopathology 67:1051-1056.

26. Tanaka, H., Negishi, H., and Maeda, H. 1990. Control of tobacco bacterial wilt by an avirulent strain of Pseudomonas solanacearunm M4S and its bacteriophage. Ann. Phytopathol.
Soc. Jpn. 56:243-246.

27. Thayer, P. L., and Stall, R. E. 1961. A survey of Xanthomonas vesicatoria resistance to streptomycin. Proc. Fla. State Hortic. Soc. 75:163-165.

28. Thomas, R. C. 1935. A bacteriophage in relation to Stewart's disease of corn. Phytopathology 25:371-372.

29. Tudor, M. S. 1999. Molecular characterization of bacteriocin-like activity in tomato racethree strains of Xanthomonas campestris pv. vesicatoria. Ph.D. diss. University of Florida, Gainesville.

30. Wilson, M., Campbell, H. L., Jones, J. B. Suslow, T. V., and Cuppels, D. A. 1997. Biological control of bacterial speck of tomato. (Abstr.) Phytopathology 86:S49.

31. Zaccardelli, M., Saccardi, A., Gambin, E., and Mazzucchi, U. 1992. Xanthomonas campestris pv. pruni bacteriophages on peach trees and their potential use for biological control Phytopathol. Mediterr. 31:133-140. 